\title{
BMJ Open Association of respiratory symptoms and asthma with occupational exposures: findings from a population-based cross-sectional survey in Telemark, Norway
}

\author{
R Abrahamsen, ${ }^{1,2}$ A K M Fell, ${ }^{1}$ M V Svendsen, ${ }^{1}$ E Andersson, ${ }^{3} \mathrm{~K}$ Torén, ${ }^{3}$ \\ P K Henneberger, ${ }^{4}{ }^{\mathrm{J}}$ Kongerud ${ }^{2,5}$
}

To cite: Abrahamsen $\mathrm{R}$, Fell AKM, Svendsen MV, et al. Association of respiratory symptoms and asthma with occupational exposures: findings from a population-based crosssectional survey in Telemark Norway. BMJ Open 2017;7: e014018. doi:10.1136/ bmjopen-2016-014018

- Prepublication history and additional material is available. To view please visit the journal (http://dx.doi.org/ 10.1136/bmjopen-2016014018).

Received 24 August 2016 Revised 15 February 2017 Accepted 24 February 2017

CrossMark

For numbered affiliations see end of article.

Correspondence to Dr Regine Abrahamsen; regine.abrahamsen@sthf.no

\section{ABSTRACT}

Objectives: The aim of this study was to estimate the prevalence of respiratory symptoms and physiciandiagnosed asthma and assess the impact of current occupational exposure.

Design: Cross-sectional analyses of the prevalence of self-reported respiratory health and association with current occupational exposure in a random sample of the general population in Telemark County, Norway.

Settings: In 2013, a self-administered questionnaire was mailed to a random sample of the general population, aged 16-50, in Telemark, Norway. The overall response rate was 33\%, comprising 16099 responders.

Outcome measures: The prevalence for respiratory symptoms and asthma, and $\mathrm{OR}$ of respiratory symptoms and asthma for occupational groups and exposures were calculated. Occupational exposures were assessed using self-reported exposure and an asthma-specific job-exposure matrix (JEM).

Results: The prevalence of physician-diagnosed asthma was $11.5 \%$. For the occupational groups, the category with agriculture/fishery workers and craft/ related trade workers was associated with wheezing and asthma attack in the past 12 months, showing $\mathrm{OR}$ 1.3 (1.1 to 1.6 ) and 1.9 (1.2 to 2.8), respectively. The group including technicians and associated professionals was also associated with wheezing $\mathrm{OR}$ 1.2 (1.0 to 1.3) and asthma attack OR 1.4 (1.1 to 1.9). The JEM data show that exposure to flour was associated with wheezing OR 3.2 (1.4 to 7.3) and woken with dyspnoea OR 3.5 (1.3 to 9.5), whereas exposures to diisocyanates, welding/soldering fumes and exposure to vehicle/motor exhaust were associated with dyspnoea OR 2.9 (1.5 to 5.7), 3.2 (1.6 to 6.4 ) and 1.4 (1.0 to 1.8$)$, respectively.

Conclusions: The observed prevalence of physiciandiagnosed asthma was $11.5 \%$. The 'manual' occupations were associated with respiratory symptoms. Occupational exposure to flour, diisocyanates, welding/soldering fumes and vehicle/ motor exhaust was associated with respiratory symptoms in the past 12 months and use of asthma

\section{Strengths and limitations of this study}

- The study included 16099 subjects from the general population in Telemark, Norway, which is a county with a variety of occupational exposures including large industrial clusters, craft, trade and agricultural activities.

- The study used cross-sectional data to investigate possible associations of self-reported respiratory symptoms and asthma with occupation and occupational exposures.

- The study is strengthened by the use of an asthma-specific job-exposure matrix on a large random sample from the general population.

- A potential study limitation is selection bias due to the cross-sectional design and nonparticipation; however, inverse probability of participation weights was used to minimise selection bias from non-participation.

medication. However, prospective data are needed to confirm the observed associations.

\section{INTRODUCTION}

Studies have shown that at least one out of three adults in Norway will experience longterm respiratory symptoms during their lifetime. ${ }^{12}$ In Europe, a substantial proportion of adults report symptoms that are initiated or exacerbated by environmental and/or occupational exposures. ${ }^{3-9}$ Globally, $15-20 \%$ of all asthma cases are considered to be related to occupation with population attributable risks (PAR) as high as 50\% among non-smokers. ${ }^{4}$ A Swedish study in 2011 reported a cumulative incidence for adult-onset asthma of $2.3 \%$ and PAR of occupational asthma of $17.3 \%$ among men and $5.1 \%$ among women. ${ }^{10}$ In southern Norway, an area which also includes Telemark 
County, it was reported in 2013 that the prevalence of wheezing and chest tightness during the past month was slightly above the country average with $5.9 \%$ and $5.1 \%$, respectively. ${ }^{11}$ No information regarding respiratory symptoms by occupation was available in that study, but the subjects with the lowest educational level had the highest prevalence of wheezing and chest tightness. The incidence of asthma in Telemark County has so far not been studied, but it is known that the use of medication for chronic respiratory disease in this region is above the national average. In 2014, the Norwegian medication prescription database reported that the number of users of medication for chronic respiratory diseases was 84 per 1000 inhabitants in Norway, while in Telemark the number was 93 per 1000 inhabitants. ${ }^{12}$

Historically, Telemark has been one of the main onshore industrialised centres in Norway. The region still has a high proportion of industrial workers employed in companies producing nitrate fertiliser, organic chlorine and chlor-alkali derivatives, polyvinylchlorides, cement and refined manganese alloys, among others. Whereas these companies have reduced the number of workers during the past decades, several smaller industrial service providers have been established. These employ many of the previous industrial workers which perform similar tasks as they did in their past jobs. Thus, inclusion of the large companies and the whole working population from the area is of importance when assessing prevalence of respiratory symptoms and impact of occupational exposure.

In Norway, there has been an increase in cases of chronic respiratory diseases referred to all Departments of Occupational and Environmental Medicine. However, studies regarding the importance of occupational exposures are still reporting conflicting results and many have a lack of specific exposure information. Moreover, there is a need for updated information regarding the impact of occupational exposures on respiratory health because production processes, raw-material and additives of products, and organisation of work change. This makes the identification of occupational groups at risk for chronic respiratory diseases difficult and hence there is uncertainty where to implement preventative measures. The aim of this study was to estimate the prevalence of respiratory symptoms and physician-diagnosed asthma and assess the impact of current occupational exposure in a large random sample from Telemark County, Norway.

\section{METHODS}

\section{Study population}

A cross-sectional survey was carried out from February to August 2013 in Telemark County, which is located in the south-eastern part of Norway and has a population of around 170000 . Grenland is the most densely populated part of the County, includes several industrial sites and has a population of 100000 . A sample of 50000 male and female subjects from the $\sim 80000$ residents in Telemark, aged $16-50$ years, was drawn randomly using the services of the Norwegian national population registry. The subjects between 16 and 18 years of age were included to take into account those who have to complete a mandatory training programme as apprentices attending school and work simultaneously or those entering the workforce without further education.

\section{Design of the study}

The participants were asked to complete a postal questionnaire (see online supplementary file 1 ) and mail it back in a prepaid envelope. Two reminders were sent by mail. The questionnaire included questions regarding occupational history and exposure, physician-diagnosed asthma, respiratory symptoms, allergy, use of asthma medication and possible confounders. The questionnaire was based on the European Community Respiratory Health Survey (ECRHS) questionnaire and a questionnaire from a similar study from west Sweden. ${ }^{10}$ The questions regarding physician-diagnosed asthma and respiratory symptoms are consistent with other studies addressing asthma and asthma-like symptoms. ${ }^{10} 13-16$

\section{Outcomes}

\section{Occupational history and exposure}

In the postal questionnaire, the participants were asked to list their occupational history in free text including occupational title, industry or sector, some key words indicating main tasks and period of employment. The participants with sufficient information regarding occupational history were then classified according to their self-reported occupation in 2013 (current occupation) with the use of the International Standard Classification of Occupations (ISCO-88) coding system ${ }^{17}$ by a trained research assistant. Each occupation was given a code according to the ISCO-88 which classifies occupations into 10 major groups that are related to formal education/qualifications. The participants were first classified into these groups as shown in table 1, and certain groups were then combined for the analyses: (1) legislators, senior officials, managers and professionals (groups I and II); (2) technicians and associated professionals (group III); (3) clerks and service workers and shop and market sales workers (groups IV and V); (4) skilled agriculture, fishery workers and craft and related trade workers (groups VI and VII) and (5) plant, machine operators and assemblers and elementary occupations (groups VIII and IX). Group 1 was used as an unexposed reference group. All occupations with at least 6 months employment were classified.

We also used an asthma-specific job-exposure matrix (JEM) developed for the northern European countries (N-JEM) to assess the participants' occupational exposures based on their self-reported jobs in $2013 .{ }^{8}{ }^{9} \mathrm{~A}$ few job titles $(n=39)$ specific to industries in Telemark County were added to the N-JEM. The N-JEM defines an 
Table 1 Population characteristics for responders and non-responders

\begin{tabular}{|c|c|c|c|c|}
\hline \multirow[b]{2}{*}{ Register based } & \multicolumn{2}{|c|}{ Responders ( $n=16$ 099) } & \multicolumn{2}{|c|}{$\begin{array}{l}\text { Non-responders } \\
(\mathrm{n}=33 \text { 901) }\end{array}$} \\
\hline & $\mathrm{n}$ & Per cent & n & Per cent \\
\hline \multicolumn{5}{|l|}{ Population size } \\
\hline Urban areas/Grenland & 10296 & 64.0 & 21348 & 63.0 \\
\hline Rural areas/outside Grenland & 5803 & 36.0 & 12553 & 37.0 \\
\hline \multicolumn{5}{|l|}{ Gender } \\
\hline Men & 7159 & 44.5 & 18358 & 54.2 \\
\hline Women & 8940 & 55.5 & 15543 & 45.8 \\
\hline \multicolumn{5}{|l|}{ Age (years) } \\
\hline $16-30$ & 5282 & 32.8 & 14626 & 43.1 \\
\hline $31-40$ & 4126 & 25.6 & 9085 & 26.8 \\
\hline \multirow[t]{2}{*}{$41-50$} & 6691 & 41.6 & 10190 & 30.1 \\
\hline & \multicolumn{2}{|c|}{$\begin{array}{l}\text { Responders } \\
(n=16099)\end{array}$} & \multicolumn{2}{|c|}{$\begin{array}{l}\text { Non-responders } \\
(\mathrm{n}=260)\end{array}$} \\
\hline Questionnaire based & $\mathrm{n}$ & Per cent & n & Per cent \\
\hline \multicolumn{5}{|l|}{ Smoking habits } \\
\hline Never-smokers & 8950 & 55.6 & 119 & 46 \\
\hline Past smokers & 3271 & 20.3 & 77 & 30 \\
\hline Current smokers & 3749 & 23.3 & 64 & 25 \\
\hline Missing & 129 & 0.8 & 0 & 0 \\
\hline \multicolumn{5}{|l|}{ Home/housing conditions } \\
\hline Detached & 11181 & 69.5 & NA & \\
\hline Row & 1565 & 9.7 & & \\
\hline Apartment & 2879 & 17.9 & & \\
\hline Other & 325 & 2.0 & & \\
\hline Missing & 149 & 0.9 & & \\
\hline \multicolumn{5}{|l|}{ Current occupation (ISCO-88) } \\
\hline Armed forces (Group 0) & 43 & 0.3 & 0 & 0 \\
\hline Legislators, senior officials and managers (Group I) & 498 & 3.1 & 5 & 2 \\
\hline Professionals (Group II) & 1748 & 10.9 & 35 & 13 \\
\hline $\begin{array}{l}\text { Technicians and associated professionals } \\
\text { (Group III) }\end{array}$ & 3000 & 18.6 & 52 & 20 \\
\hline Clerks (Group IV) & 674 & 4.2 & 12 & 5 \\
\hline $\begin{array}{l}\text { Service workers and shop and market sales workers } \\
\text { (Group V) }\end{array}$ & 1717 & 10.7 & 46 & 18 \\
\hline Skilled agriculture and fishery workers (Group VI) & 158 & 1.0 & 2 & 1 \\
\hline Craft and related trade workers (Group VII) & 1240 & 7.7 & 35 & 13 \\
\hline $\begin{array}{l}\text { Plant and machine operators and assemblers } \\
\text { (Group VIII) }\end{array}$ & 779 & 4.8 & 21 & 8 \\
\hline Elementary occupations (Group IX) & 438 & 2.7 & 12 & 5 \\
\hline Missing* & 5804 & 36.1 & 40 & 15 \\
\hline
\end{tabular}

occupation as exposed based on the assumption that at least half of the subjects with this specific code would have a high probability of being exposed to irritants or allergens. As an example, the category 'flour-associated antigens' consists of bakers, pastry makers, grain millers and operators of baked goods. The N-JEM data can be collapsed into six main exposure groups: high molecular weight (HMW) agents, low molecular weight (LMW) agents, irritating agents, accidental peak exposures to irritants, uncertain or low exposures and an unexposed reference group.
Respiratory symptoms

Asthma, use of asthma medication, respiratory symptoms and nasal allergies were defined as positive responses to the following questions: ever asthma: 'Have you ever had asthma?', physician-diagnosed asthma: 'Have you been diagnosed by a physician as having asthma?', asthma attack: 'Have you had an attack of asthma in the past 12 months?', use of asthma medication: 'Do you currently use asthma medication?', ever wheezing: 'Have you ever had whistling or wheezing in the chest?', wheezing past 12 months: 'Have you had whistling or wheezing in the 
chest at any occasion during the past 12 months?', woken with dyspnoea: 'Have you been woken by an attack of shortness of breath at any time in the past 12 months?', chronic cough: 'Have you had a persistent cough during the last years?', productive cough: 'Do you usually bring up any phlegm or do you have phlegm in your chest, that is difficult to cough up?', nasal allergy as a marker for allergic status: 'Do you have an allergy with nasal symptoms, including hay-fever?'. These symptoms were used to describe the population, while only the symptoms addressing the past 12 months, current asthma medication and physician-diagnosed asthma were used to assess associations with current occupation or exposure. A symptom score was then calculated based on the number of affirmative answers to the four questions addressing symptoms, and use of asthma medication in the past 12 months.

\section{Covariates and confounders}

The participant's age, gender and residential address was census-derived, whereas housing condition, smoking habits, household smoking and exposure to damp and mould at home was based on self-report from the questionnaires. For housing condition, the following question was used: 'What type of home do you live in?' The alternative categories were: detached house, row house/ semidetached house, apartment or other.

Smoking was defined as follows: Current smokers answered affirmative to the question: 'Do you smoke every day (also applies if you only smoke a few cigarettes, cigars or light a pipe each day)?' or the question: 'Do you only smoke occasionally (not each day, but weekends, parties or similar)?' Past smoker were those who answered affirmative to the question: 'Did you use to smoke?' Those not answering any of the three questions were defined as missing, and the remaining as neversmokers. Passive smoking was defined as an affirmative answer to 'Does anyone smoke inside your current home?'

Damp and mould exposure at home was defined as positive answer to at least one of the following questions: 'Have you ever had the following in your property? Water damage inside in the dwelling on walls, floors or ceilings? Dented plastic mats, stained plastic or hardwood flooring that has been darkened by the moisture?' or 'Visible mould on walls, floors or ceilings?'

\section{Ethics}

The REC only allowed the sending of two reminders to the study sample. The participants signed and returned a consent form.

\section{Statistical analysis}

The subjects with missing or insufficient information regarding current occupation were excluded from the analyses addressing occupational exposure. When respondents left an answer blank, these were handled as 'no' (not having the symptom). Sensitivity analyses were performed with and without missing. The selection of individual jobs for the analysis assessing occupation/ exposure and respiratory outcomes was based on the work codes with at least 100 respondents in the major groups 5-9 (1-4 are those with non-exposure or low exposure) supplemented with the occupational groups previously identified as having changed work because exposures at work affected their breathing. ${ }^{18} \chi^{2}$ and Fisher's exact tests were used to compare groups with regard to the prevalence of respiratory symptoms. To estimate the effects of occupations, occupational groups and occupational exposures, the ORs and corresponding 95\% CIs were computed by logistical regression. Four different analyses were performed separately; for each occupation, for the occupational groups, for large exposure groups and for the single exposures. Unadjusted and adjusted estimates were calculated. The estimates were adjusted for age, gender, area of residence, smoking status, household smoking, damp and mould at home and housing conditions. To adjust for possible participation bias, all analyses were performed on weighted data sets. The weighting was based on inverse probability of participation among all 50000 invited and calculated for each combination of gender, 5-year age intervals and area of residence by grouping of postal codes. ${ }^{19}$ Each combination of these background variables had at least 19 responders when calculating weights. Additionally, weights based on inverse probability of participation by use of asthma medication and chronic cough derived from 260 participants in the nonresponder study were performed. The final weights used in the current analysis were the product of these two weights. As part of the sensitivity analysis, the statistical analyses were performed with and without these weights to evaluate how adjusting for non-response affected the study results. ${ }^{19}$ PAR was calculated for some exposure and symptoms. The statistical significance level was set at $\mathrm{p}<0.05$ and results reaching significance are marked in bold in the tables. Statistical analysis was performed with IBM SPSS Statistics for Windows (V.23, IBM SPSS, Armonk, New York, USA) using the SPSS complex sample module where appropriate.

\section{RESULTS}

\section{Participation}

The overall response rate to the Telemark study was 33\%, comprising 16099 responders. Out of the 16099 responders, $10004(20 \%)$ responded to the first mailed questionnaire, while $3123(6 \%)$ responded to the first reminder and $2972(6 \%)$ to the last reminder. The inclusion of participants stopped 3 months after the second reminder was mailed. Eighty-three per cent of the responders (13 302) reported being employed in the past 12 months. Among all 16099 responders, $10295(63.9 \%)$ reported their occupation in 2013 and were classified by the ISCO-88 (table 1). Repeating the analyses without responses with missing values or 
without adjustment for non-participation did not significantly influence the results presented.

\section{Study population}

The population characteristics of responders and nonresponders are presented in table 1.

The whole sample including 16099 responders contained more women than men $(55.5 \%$ vs $44.5 \%$, respectively). Approximately twice as many lived in the urban area of Grenland $(64.0 \%)$ as outside this area $(36.0 \%)$. Seventy per cent of the subjects lived in a detached house and $18 \%$ in apartments. By age, $41.6 \%$ of the responders were between 41 and 50 years, while $32.8 \%$ and $25.6 \%$ were between 16 and 30 years and 31 and 40 years, respectively. A little more than half $(55.6 \%)$ of the responders were never-smokers while the current smokers (23.3\%) slightly outnumbered the past smokers (20.3\%).

\section{Prevalence of respiratory symptoms, smoking habits and occupation}

The prevalence of respiratory symptoms and asthma are shown in figure 1 . The most common respiratory outcomes ever experienced were nasal allergies (29.9\%), wheezing (26.7\%) and chronic cough $(20.6 \%)$. The most common outcome in the past 12 months was wheezing $(20.0 \%)$. The prevalence of a history of physician-diagnosed asthma was $11.5 \%$, and $4.1 \%$ reported an asthma attack in the past 12 months. Among the 2137 responders (13.3\%) who reported 'ever asthma', 1727 reported their age at which they first experienced asthma symptoms and $71.3 \%$ of those reported to have had their first symptoms before they turned 18 years $(n=1231)$. The prevalence of physiciandiagnosed asthma declined with advancing age: $12.4 \%$ if $16-30$ years, $11.4 \%$ if $31-40$ years and $10.9 \%$ if $41-$ 50 years. Out of the 1839 responders reporting physician-diagnosed asthma, $893 \quad(48.1 \%)$ reported current use of asthma medication and 531 (28.6\%) reported an asthma attack in the past 12 months.

The prevalence of respiratory symptoms and diseases by the possible confounders, age, gender, area of residence, smoking habits and housing conditions, is shown in table 2.

Ever having respiratory symptoms and woken by dyspnoea attack in the past 12 months, but not the asthma outcomes are more common in Grenland as compared with outside Grenland. The prevalence of physiciandiagnosed asthma, use of asthma medication and respiratory symptoms in the past 12 months were associated with smoking and housing condition. The prevalence of physician-diagnosed asthma decreased with increasing age and was also more common among women than men. The prevalence of respiratory symptoms in the past 12 months and nasal allergies were associated with age category.

\section{Association of self-reported current job categories and specific occupation with respiratory symptoms and disease}

The relationship between respiratory symptoms/diseases and the participants' occupations is shown in table 3 .

Using the main occupational groups, the category with the combination agriculture/fishery workers and craft/related trade workers showed the highest OR for wheezing and asthma attack (table 3). The PARs for asthma attack during the past 12 months for the main occupational groups 2 and 4 were both $11 \%$. The strongest associations between respiratory symptoms and current job category were for health-associated professionals (OR between 1.4 and 2.1) and welders (OR 5.5) (table 3).
Figure 1 The prevalence of respiratory symptoms and asthma ever and for the past 12 months in the Telemark study.

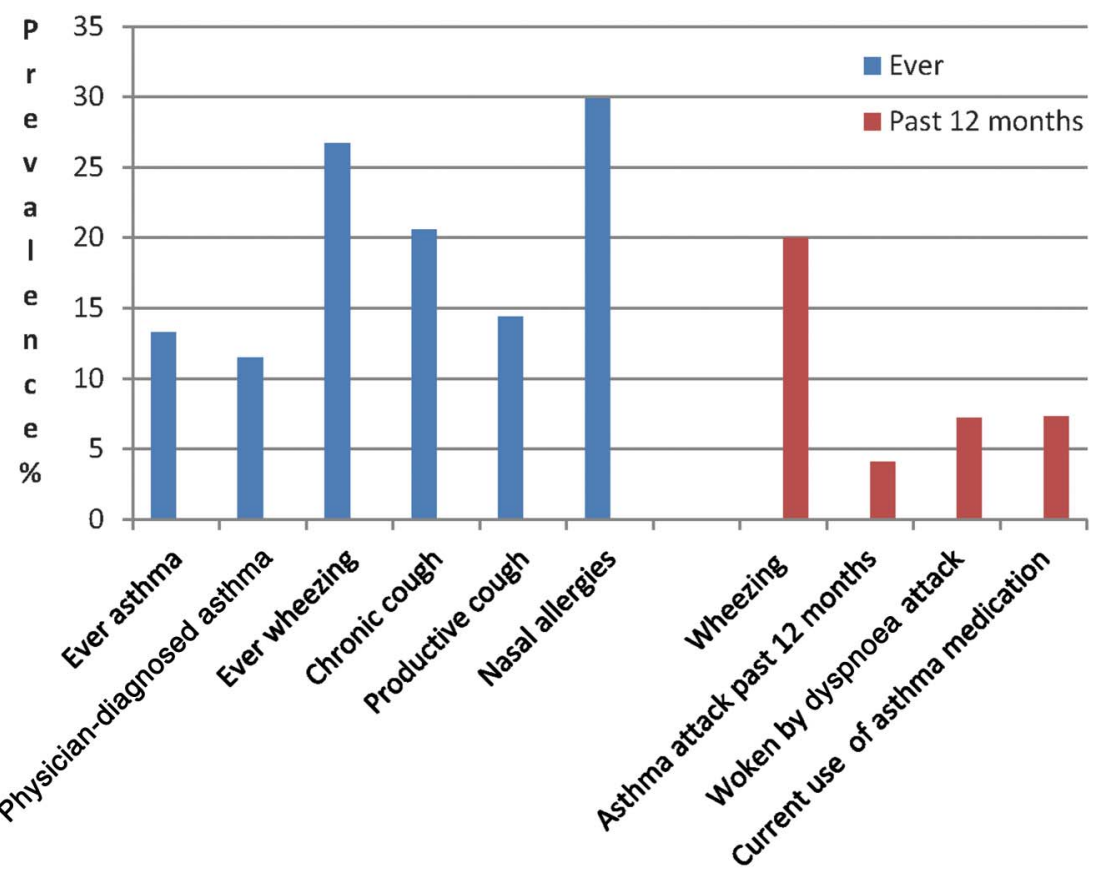


Table 2 Prevalence of asthma, respiratory symptoms ever and symptoms during the past 12 months by possible confounders: area of residence, smoking habits, housing conditions, age and gender

\begin{tabular}{|c|c|c|c|c|c|c|c|c|c|c|c|c|c|c|c|c|c|c|c|c|}
\hline \multirow[b]{2}{*}{ Symptoms or disease } & \multirow[b]{2}{*}{$\begin{array}{l}\text { Number } \\
\text { Yes/no }\end{array}$} & \multicolumn{3}{|c|}{ Area of residence } & \multicolumn{4}{|c|}{ Smoking habits } & \multicolumn{4}{|c|}{ Age (years) } & \multicolumn{3}{|l|}{ Gender } & \multicolumn{5}{|c|}{ Housing conditions } \\
\hline & & Grenland & $\begin{array}{l}\text { Outside } \\
\text { Grenland }\end{array}$ & p Value ${ }^{\star}$ & $\begin{array}{l}\text { Never- } \\
\text { smokers }\end{array}$ & $\begin{array}{l}\text { Past } \\
\text { smokers }\end{array}$ & $\begin{array}{l}\text { Current } \\
\text { smokers }\end{array}$ & $p$ Value & $16-30$ & $31-40$ & $41-50$ & $\mathrm{p}$ Value & Men & Women & $p$ Value ${ }^{*}$ & Detached & $\begin{array}{l}\text { Row/ } \\
\text { semidetached }\end{array}$ & Apartment & Other & p Value \\
\hline \multicolumn{21}{|l|}{ Ever } \\
\hline Ever asthma & $2137 / 13962$ & $\begin{array}{l}1348 \\
(13.1)\end{array}$ & $\begin{array}{r}789 \\
(13.6)\end{array}$ & 0.371 & $\begin{array}{l}1128 \\
(12.6)\end{array}$ & $\begin{array}{c}471 \\
(14.4)\end{array}$ & $\begin{array}{c}526 \\
(14.0)\end{array}$ & 0.012 & $\begin{array}{c}759 \\
(14.4)\end{array}$ & $\begin{array}{c}553 \\
(13.4)\end{array}$ & $\begin{array}{c}825 \\
(12.3)\end{array}$ & 0.005 & $\begin{array}{c}871 \\
(12.2)\end{array}$ & $\begin{array}{l}1266 \\
(14.2)\end{array}$ & $<0.001$ & $\begin{array}{l}1416 \\
(12.7)\end{array}$ & $232(14.8)$ & $432(15.0)$ & $45(13.8)$ & 0.002 \\
\hline $\begin{array}{l}\text { Physician-diagnosed } \\
\text { asthma }\end{array}$ & $1857 / 14042$ & $\begin{array}{l}1178 \\
(11.4)\end{array}$ & $\begin{array}{r}679 \\
(11.7)\end{array}$ & 0.626 & $\begin{array}{c}983 \\
(11.0)\end{array}$ & $\begin{array}{c}407 \\
(12.4)\end{array}$ & $\begin{array}{c}457 \\
(12.2)\end{array}$ & 0.032 & $\begin{array}{c}656 \\
(12.4)\end{array}$ & $\begin{array}{c}471 \\
(11.4)\end{array}$ & $\begin{array}{r}730 \\
(10.9)\end{array}$ & 0.036 & $\begin{array}{c}757 \\
(10.6)\end{array}$ & $\begin{array}{l}1100 \\
(12.3)\end{array}$ & 0.001 & $\begin{array}{l}1226 \\
(11.0)\end{array}$ & 207 (13.2) & 376 (13.1) & $39(12.0)$ & 0.002 \\
\hline Ever wheezing & $4294 / 11805$ & $\begin{array}{l}2788 \\
(27.1)\end{array}$ & $\begin{array}{l}1506 \\
(26.0)\end{array}$ & 0.124 & $\begin{array}{l}1893 \\
(21.2)\end{array}$ & $\begin{array}{c}988 \\
(30.2)\end{array}$ & $\begin{array}{l}1399 \\
(37.3)\end{array}$ & $<0.001$ & $\begin{array}{l}1323 \\
(25.0)\end{array}$ & $\begin{array}{l}1125 \\
(27.3)\end{array}$ & $\begin{array}{l}1846 \\
(27.6)\end{array}$ & 0.005 & $\begin{array}{l}1858 \\
(26.0)\end{array}$ & $\begin{array}{l}2436 \\
(27.2)\end{array}$ & 0.067 & $\begin{array}{l}2919 \\
(26.1)\end{array}$ & $436(27.9)$ & $837(29.1)$ & $81(24.9)$ & 0.008 \\
\hline Chronic cough & $3319 / 12780$ & $\begin{array}{l}2210 \\
(21.5)\end{array}$ & $\begin{array}{r}1109 \\
(19.1)\end{array}$ & $<0.001$ & $\begin{array}{l}1663 \\
(18.6)\end{array}$ & $\begin{array}{c}636 \\
(19.4)\end{array}$ & $\begin{array}{l}1001 \\
(26.7)\end{array}$ & $<0.001$ & $\begin{array}{l}1082 \\
(20.5)\end{array}$ & $\begin{array}{c}853 \\
(20.7)\end{array}$ & $\begin{array}{l}1384 \\
(20.7)\end{array}$ & 0.959 & $\begin{array}{l}1334 \\
(18.6)\end{array}$ & $\begin{array}{l}1985 \\
(22.2)\end{array}$ & $<0.001$ & $\begin{array}{l}2234 \\
(20.0)\end{array}$ & 347 (22.2) & $653(22.7)$ & $68(20.9)$ & 0.006 \\
\hline Productive cough & $2363 / 13736$ & $\begin{array}{l}1589 \\
(15.4)\end{array}$ & $\begin{array}{r}774 \\
(13.3)\end{array}$ & $<0.001$ & $\begin{array}{l}1006 \\
(11.2)\end{array}$ & $\begin{array}{c}425 \\
(13.0)\end{array}$ & $\begin{array}{c}921 \\
(24.6)\end{array}$ & $<0.001$ & $\begin{array}{c}830 \\
(15.7)\end{array}$ & $\begin{array}{c}533 \\
(12.9)\end{array}$ & $\begin{array}{l}1000 \\
(14.9)\end{array}$ & 0.001 & $\begin{array}{l}1018 \\
(14.2)\end{array}$ & $\begin{array}{l}1345 \\
(15.0)\end{array}$ & 0.145 & $\begin{array}{l}1494 \\
(13.4)\end{array}$ & $252(16.1)$ & $539(18.7)$ & $64(19.7)$ & $<0.001$ \\
\hline Nasal allergies & $4814 / 12085$ & $\begin{array}{l}3148 \\
(30.6)\end{array}$ & $\begin{array}{r}1666 \\
(28.7)\end{array}$ & 0.013 & $\begin{array}{l}2682 \\
(30.0)\end{array}$ & $\begin{array}{l}1030 \\
(31.5)\end{array}$ & $\begin{array}{l}1087 \\
(29.0)\end{array}$ & 0.073 & $\begin{array}{l}1461 \\
(27.7)\end{array}$ & $\begin{array}{l}1298 \\
(31.5)\end{array}$ & $\begin{array}{l}2055 \\
(30.7)\end{array}$ & $<0.001$ & $\begin{array}{l}2122 \\
(29.6)\end{array}$ & $\begin{array}{l}2692 \\
(30.1)\end{array}$ & 0.522 & $\begin{array}{l}3388 \\
(30.3)\end{array}$ & 504 (32.2) & $832(28.9)$ & $68(20.9)$ & $<0.001$ \\
\hline \multicolumn{21}{|l|}{ Past 12 months } \\
\hline Wheezing & $3226 / 12963$ & $\begin{array}{l}2093 \\
(20.3)\end{array}$ & $\begin{array}{r}1133 \\
(19.5)\end{array}$ & 0.227 & $\begin{array}{l}1378 \\
(15.4)\end{array}$ & $\begin{array}{c}620 \\
(19.0)\end{array}$ & $\begin{array}{l}1213 \\
(32.4)\end{array}$ & $<0.001$ & $\begin{array}{l}1021 \\
(19.3)\end{array}$ & $\begin{array}{c}792 \\
(19.2)\end{array}$ & $\begin{array}{l}1413 \\
(21.1)\end{array}$ & 0.015 & $\begin{array}{l}1371 \\
(19.2)\end{array}$ & $\begin{array}{l}1855 \\
(20.7)\end{array}$ & 0.012 & $\begin{array}{l}2164 \\
(19.4)\end{array}$ & $333(21.3)$ & $645(22.4)$ & $65(20.0)$ & 0.002 \\
\hline Asthma attack & $664 / 15035$ & $\begin{array}{l}447 \\
(4.3)\end{array}$ & $\begin{array}{c}217 \\
(3.7)\end{array}$ & 0.070 & $\begin{array}{c}345 \\
(3.9)\end{array}$ & $\begin{array}{c}138 \\
(4.2)\end{array}$ & $\begin{array}{c}174 \\
(4.6)\end{array}$ & 0.119 & $\begin{array}{c}222 \\
(4.2)\end{array}$ & $\begin{array}{r}136 \\
(3.3)\end{array}$ & $\begin{array}{r}306 \\
(4.6)\end{array}$ & 0.005 & $\begin{array}{c}211 \\
(2.9)\end{array}$ & $\begin{array}{c}453 \\
(5.1)\end{array}$ & $<0.001$ & $\begin{array}{r}412 \\
(3.7)\end{array}$ & $71(4.5)$ & $162(5.6)$ & $13(4.0)$ & $<0.001$ \\
\hline Woken by dyspnoea & $1179 / 14920$ & $\begin{array}{l}790 \\
(7.7)\end{array}$ & $\begin{array}{r}389 \\
(6.7)\end{array}$ & 0.024 & $\begin{array}{r}533 \\
(6.0)\end{array}$ & $\begin{array}{r}243 \\
(7.4)\end{array}$ & $\begin{array}{c}396 \\
(10.6)\end{array}$ & $<0.001$ & $\begin{array}{r}318 \\
(6.0)\end{array}$ & $\begin{array}{r}264 \\
(6.4)\end{array}$ & $\begin{array}{r}597 \\
(8.9)\end{array}$ & $<0.001$ & $\begin{array}{r}503 \\
(7.0)\end{array}$ & $\begin{array}{r}676 \\
(7.6)\end{array}$ & 0.201 & $\begin{array}{r}766 \\
(6.9)\end{array}$ & $126(8.1)$ & $258(9.0)$ & $22(6.8)$ & 0.001 \\
\hline $\begin{array}{l}\text { Current use of } \\
\text { asthma medication }\end{array}$ & $1171 / 14928$ & $\begin{array}{l}730 \\
(7.1)\end{array}$ & $\begin{array}{c}441 \\
(7.6)\end{array}$ & 0.242 & $\begin{array}{r}610 \\
(6.8)\end{array}$ & $\begin{array}{c}262 \\
(8.0)\end{array}$ & $\begin{array}{c}291 \\
(7.8)\end{array}$ & 0.035 & $\begin{array}{r}376 \\
(7.1)\end{array}$ & $\begin{array}{c}262 \\
(6.3)\end{array}$ & $\begin{array}{l}533 \\
(8.0)\end{array}$ & 0.006 & $\begin{array}{r}435 \\
(6.1)\end{array}$ & $\begin{array}{r}736 \\
(8.2)\end{array}$ & $<0.001$ & $\begin{array}{c}762 \\
(6.8)\end{array}$ & $138(8.8)$ & $243(8.4)$ & $23(7.1)$ & 0.002 \\
\hline
\end{tabular}




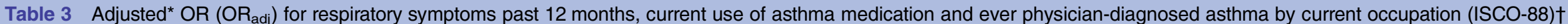

\begin{tabular}{|c|c|c|c|c|c|c|c|}
\hline \multirow[b]{2}{*}{ Major groups (ISCO-88 first digit) } & \multicolumn{6}{|c|}{ Lower respiratory tract } & \multirow[b]{2}{*}{$\begin{array}{l}\text { Physician- } \\
\text { diagnosed } \\
\text { asthma } \\
\text { OR }_{\text {adj }}\end{array}$} \\
\hline & $\begin{array}{l}\text { Total } \\
\mathbf{N}\end{array}$ & $\begin{array}{l}\text { Wheezing } \\
\text { OR }_{\text {adj }}\end{array}$ & $\begin{array}{l}\text { Woken with } \\
\text { dyspnoea } \\
\text { OR }_{\text {adj }}\end{array}$ & $\begin{array}{l}\text { Asthma } \\
\text { attack } \\
\text { OR }_{\text {adj }}\end{array}$ & $\begin{array}{l}\text { Use of asthma } \\
\text { medication } \\
\text { OR }_{\text {adj }}\end{array}$ & $\begin{array}{l}\text { At least one } \\
\text { symptom } \\
\text { last } 12 \text { months } \\
\text { OR }_{\text {adj }}\end{array}$ & \\
\hline $\begin{array}{l}\text { 1. Legislators, senior officials and managers and } \\
\text { professionals and armed forces (Groups } 0, I \text { and } \\
\text { II only)-Reference }\end{array}$ & 2204 & 1 & 1 & 1 & 1 & 1 & 1 \\
\hline $\begin{array}{l}\text { 2. Technicians and associated professionals } \\
\text { (Group III) }\end{array}$ & 3091 & $1.2(1.0$ to 1.3$)$ & $0.95(0.76$ to 1.2$)$ & $1.4(1.1$ to 1.9$)$ & $1.2(0.99$ to 1.5$)$ & $1.1(0.99$ to 1.3$)$ & $0.95(0.79$ to 1.1$)$ \\
\hline $\begin{array}{l}\text { 3. Clerks and Service workers and shop and } \\
\text { market sales workers (Groups IV and V) }\end{array}$ & 2547 & $1.1(0.95$ to 1.3$)$ & $1.0(0.82$ to 1.3$)$ & $1.3(0.95$ to 1.8$)$ & $1.0(0.82$ to 1.3$)$ & 1.1 (0.93 to 1.2$)$ & $0.89(0.74$ to 1.1$)$ \\
\hline $\begin{array}{l}\text { 4. Skilled agriculture and fishery workers and craft } \\
\text { and related trade workers (Groups VI and VII) }\end{array}$ & 1467 & $1.3(1.1$ to 1.6$)$ & $1.2(0.91$ to 1.6$)$ & $1.9(1.2$ to 2.8$)$ & $1.1(0.83$ to 1.6$)$ & $1.2(1.0$ to 1.5$)$ & $0.80(0.62$ to 1.0$)$ \\
\hline $\begin{array}{l}\text { 5. Plant and machine operators and assemblers } \\
\text { and Elementary occupations(Groups VIII and IX) }\end{array}$ & 1294 & $1.2(1.0$ to 1.5$)$ & $1.2(0.90$ to 1.6$)$ & $1.1(0.73$ to 1.7$)$ & $1.1(0.81$ to 1.5$)$ & $1.2(1.0$ to 1.5$)$ & $0.80(0.63$ to 1.0$)$ \\
\hline \multicolumn{8}{|l|}{ Specific occupations (ISCO-88 four digits) } \\
\hline $\begin{array}{l}\text { Legislators, senior officials, managers, } \\
\text { professionals and armed forces (Groups } 0, \text { I and II } \\
\text { only)-Reference }\end{array}$ & 2204 & 1 & 1 & 1 & 1 & 1 & 1 \\
\hline \multicolumn{8}{|l|}{ Healthcare professionals } \\
\hline $\begin{array}{l}\text { Health-associated professionals not classified } \\
\text { elsewhere (3229) }\end{array}$ & 630 & 1.4 (1.1 to 1.7$)$ & $1.2(0.82$ to 1.8$)$ & $1.4(0.87$ to 2.4$)$ & 2.1 (1.5 to 3.1$)$ & $1.4(1.1$ to 1.7$)$ & $0.79(0.56$ to 1.1$)$ \\
\hline Nursing (3230-3232) & 435 & $1.2(0.86$ to 1.5$)$ & $0.79(0.49$ to 1.3$)$ & $1.2(0.68$ to 2.1$)$ & $0.78(0.48$ to 1.3$)$ & $1.0(0.77$ to 1.4$)$ & $0.87(0.60$ to 1.2$)$ \\
\hline Cooks (5122) & 168 & $1.4(0.90$ to 2.1$)$ & $1.2(0.65$ to 2.1$)$ & 1.5 (0.65 to 3.3$)$ & $1.2(0.57$ to 2.5$)$ & $1.3(0.84$ to 1.9$)$ & $0.91(0.54$ to 1.5$)$ \\
\hline Waiters, waitresses and bartenders (5123) & 163 & $1.1(0.75$ to 1.7$)$ & $1.5(0.84$ to 2.7$)$ & $1.8(0.89$ to 3.7$)$ & $1.3(0.67$ to 2.4$)$ & $1.4(0.93$ to 2.0$)$ & $1.3(0.81$ to 2.1$)$ \\
\hline Hairdressers (5141) & 81 & $1.5(0.82$ to 2.6$)$ & $0.96(0.34$ to 2.7$)$ & $1.8(0.57$ to 5.8$)$ & $0.94(0.29$ to 3.1$)$ & $1.5(0.85$ to 2.5$)$ & $0.82(0.37$ to 1.8$)$ \\
\hline Shops salesperson (5220) & 1084 & $1.1(0.86$ to 1.3$)$ & $1.0(0.73$ to 1.4$)$ & $1.2(0.77$ to 1.9$)$ & $1.1(0.81$ to 1.6$)$ & $1.1(0.87$ to 1.3$)$ & $0.78(0.60$ to 1.0$)$ \\
\hline Gardeners (6113) & 47 & $0.88(0.37$ to 2.1$)$ & $1.4(0.42$ to 4.8$)$ & $1.2(0.16$ to 9.2$)$ & $0.94(0.20$ to 4.4$)$ & $0.95(0.43$ to 2.1$)$ & $0.72(0.24$ to 2.2$)$ \\
\hline Carpenters and jointers (7124) & 178 & $1.3(0.87$ to 2.0$)$ & $1.0(0.52$ to 2.1$)$ & $1.7(0.60$ to 4.5$)$ & $0.82(0.35$ to 1.9$)$ & $1.3(0.84$ to 1.9$)$ & $0.79(0.43$ to 1.4$)$ \\
\hline Building workers $(7120-7123,7129,7133,9313)$ & 213 & $0.71(0.45$ to 1.1$)$ & $0.94(0.49$ to 1.8$)$ & $0.60(0.19$ to 1.9$)$ & $0.45(0.19$ to 1.1$)$ & $0.73(0.48$ to 1.1$)$ & $0.39(0.21$ to 0.73$)$ \\
\hline Electricians $(7137,7241,7245)$ & 203 & $1.5(0.97$ to 2.2$)$ & $1.4(0.74$ to 2.6$)$ & $1.5(0.63$ to 3.5$)$ & $0.89(0.44$ to 1.8$)$ & $1.3(0.90$ to 1.9$)$ & $0.69(0.41$ to 1.2$)$ \\
\hline Welders (7212) & 35 & $1.7(0.79$ to 3.8$)$ & $5.5(2.1$ to 14$)$ & $0.60(0.072$ to 5.0$)$ & $1.3(0.44$ to 3.9$)$ & $1.9(0.86$ to 4.1$)$ & 0.66 (0.23 to 2.0$)$ \\
\hline Sheet metal workers (7213) & 38 & $1.6(0.73$ to 3.6$)$ & $0.76(0.15$ to 3.9$)$ & $1.1(0.14$ to 9.4$)$ & 1.3 (0.39 to 4.2$)$ & 1.4 (0.63 to 2.9$)$ & $0.38(0.091$ to 1.6$)$ \\
\hline Machinery mechanics (7230-7233) & 255 & $1.2(0.82$ to 1.7$)$ & $0.54(0.27$ to 1.1$)$ & $1.0(0.47$ to 2.4$)$ & $0.70(0.36$ to 1.3$)$ & $1.1(0.76$ to 1.5$)$ & 0.63 (0.39 to 1.0$)$ \\
\hline Motor vehicle drivers (8320-8324) & 205 & $1.2(0.81$ to 1.7$)$ & $1.2(0.66$ to 2.0$)$ & $0.62(0.21$ to 1.8$)$ & $1.1(0.61$ to 1.9$)$ & $1.2(0.85$ to 1.7$)$ & $0.66(0.39$ to 1.1$)$ \\
\hline Cleaners $(9131,9132)$ & 185 & $0.76(0.47$ to 1.2$)$ & $0.63(0.27$ to 1.4$)$ & $1.4(0.61$ to 3.2$)$ & $1.6(0.80$ to 3.1$)$ & $0.90(0.58$ to 1.4$)$ & $0.92(0.51$ to 1.6$)$ \\
\hline Agricultural labour (9211) & 53 & $1.3(0.58$ to 2.9$)$ & $0.28(0.038$ to 2.1$)$ & $1.2(0.28$ to 5.2$)$ & $0.24(0.032$ to 1.8$)$ & $1.0(0.45$ to 2.3$)$ & $1.1(0.46$ to 2.7$)$ \\
\hline
\end{tabular}

Results reaching significance, $\mathrm{p}<0.05$, are marked in bold.

${ }^{*}$ Adjusted for age, gender, area of residence, smoking, passive smoking, housing conditions, damp and mould at home and nasal allergy.

†Self-reported occupation categorised by the researchers using ISCO-88.

ISCO-88, International Standard Classification of Occupations. 
Association between occupational exposure (N-JEM) and respiratory symptoms and asthma

To further explore the relationship between occupational exposure and respiratory symptoms and diseases, we used the N-JEM to assess the exposures (table 4).

As shown in table 4, irritating agents showed a statistically significant elevated OR for woken with dyspnoea. When analysing specific exposure subgroup from the N-JEM (table 4), flour exposure had the highest ORs for respiratory symptoms in the past 12 months. Other specific exposures with statistically significant elevated ORs were diisocyanates, welding/soldering fumes and vehicle/motor exhaust. Low risks were observed for pharmaceutical product agents, epoxy chemicals, metal working fluids and peak exposures to irritants. The PAR for having at least one symptom during the past 12 months for the exposures flour, diisocyanates, welding/ soldering fumes and vehicle/motor exhaust was $0.8 \%$, $1.8 \%, 1.1 \%$ and $2.0 \%$, respectively.

\section{DISCUSSION}

In this population-based study, the prevalence of physician-diagnosed asthma was $11.5 \%$. The study identified occupations and occupational exposures associated with respiratory symptoms in the past 12 months, use of asthma medication and respiratory diseases by the use of an asthma-specific JEM. The high-risk occupations associated with several respiratory outcomes were health-associated professionals and welders. The specific occupational exposures that had associations with respiratory symptoms were flour, diisocyanates, welding/ soldering fumes and vehicle/motor exhaust. The study also identified negative associations between some respiratory symptoms and exposures, which may indicate the presence of healthy worker effects.

The prevalence of physician-diagnosed asthma was higher in Telemark than in a similar study conducted in Gothenburg in 2008 which found a prevalence of $8.3 \% .^{20}$ Also, the prevalence of symptoms in the past 12 months and use of asthma medication was slightly more common in our study compared with that study. Globally, the asthma prevalence among adults is highest in high-income regions and varies between $1 \%$ and $21 \%$, with estimates of $\sim 6-20 \%$ for different parts of western Europe and $11 \%$ for Norway. ${ }^{21}$ While there is no previous estimates on physician-diagnosed asthma from Telemark County, the prevalence of wheezing in the past 12 months was $5.9 \%$ in southeast Norway in 2013. ${ }^{11}$ In our study, a larger proportion of responders and non-responders reported wheezing in the past 12 months, with $20.0 \%$ and $21.3 \%$, respectively. This finding indicates that further assessment of risk factors for respiratory disease is needed in Telemark.

The prevalence of physician-diagnosed asthma and respiratory symptoms in the past 12 months decreased with increasing age and was more common among women as compared with men $(12.3 \%$ vs $10.6 \%$, respectively). This finding is in contrast with the Hordaland study from west Norway where $6.1 \%$ of men and $5.7 \%$ of women reported physician-diagnosed asthma. ${ }^{6}$ In that study, few associations between occupational exposures assessed by the ALOHA JEM were detected by the use of three categories of exposure, biological dust, mineral dust and gas or fumes, and further division into non-exposed, low or high exposed within these categories. There are some important differences between our study and the Hordaland study. The latter was published in 2009 but includes data collected two decades ago. The applied JEM was not adjusted to the geographical area, and used wide exposure categories which may have introduced misclassification of exposure. Further, the authors stated that their population sample was likely to be representative for the whole country, whereas our study includes an area with high levels of industrial activity (Grenland).

In terms of smoking habits, the prevalence of physician-diagnosed asthma did not differ between smoking categories in our study. This is in line with the observation in the study from west Sweden where asthma incidence rates during the never-smoking years were the same as during the smoking years..$^{20}$ Our results also showed that respiratory symptoms were associated with living in an urban area and housing conditions. Similar observations were reported by Montnémery $e t a t^{22}$ in a study from Sweden, where living by the sea and urban living were associated with asthma. That study also reported an association between asthma and unskilled and semiskilled workers, although the results were not statistically significant. We have adjusted our results for smoking, housing condition, damp and mould, and area of living. These variables may be considered as indicators of socioeconomic status, although income is more commonly used. The Telemark study does not include income data. As differences in workers' salaries are relatively small in Norway, income may not be well suited to describe socioeconomic differences. ${ }^{23}$

Our study identified two job categories that were associated with different respiratory symptoms in the past 12 months and use of asthma medication: healthassociated professionals and welders. These results support earlier findings from cross-sectional studies from specific industries or sectors showing that working as a healthcare professional is associated with respiratory symptoms and asthma. ${ }^{24-26}$ Healthcare professionals consist of several occupational groups with a variety of potential exposures to occupational hazards that may have asthmagenic and/or allergenic properties. Especially, exposures to cleaning and disinfecting products may explain the increased risk of occupational asthma. ${ }^{26}$ In our study, we observed that health-associated professionals were associated with several respiratory symptoms in the past 12 months and the use of current asthma medication. This is in line with findings from Lillienberg $e t a l^{8}$ showing an increased risk for new-onset asthma in female nurses (HR 1.5, 95\% CI 0.95 to 2.1). 
Table 4 Adjusted* OR $\left(\mathrm{OR}_{\text {adj }}\right)$ for respiratory symptoms past 12 months, current use of asthma medication and ever physician-diagnosed asthma by exposure generated from ISCO-88 work codes and the use of N-JEM†

\begin{tabular}{|c|c|c|c|c|c|c|c|}
\hline \multirow[b]{2}{*}{ Exposure category } & \multirow[b]{2}{*}{$\begin{array}{l}\text { Total } \\
\text { number }\end{array}$} & \multirow[b]{2}{*}{$\begin{array}{l}\text { Wheezing last } \\
12 \text { months } \\
\text { OR }_{\text {adj }}\end{array}$} & \multirow[b]{2}{*}{$\begin{array}{l}\text { Woken with } \\
\text { dyspnoea } \\
\text { OR }_{\text {adj }}\end{array}$} & \multirow[b]{2}{*}{$\begin{array}{l}\text { Asthma attack } \\
\text { OR }_{\text {adj }}\end{array}$} & \multicolumn{3}{|c|}{ Lower respiratory tract } \\
\hline & & & & & $\begin{array}{l}\text { Use of asthma } \\
\text { medication } \\
\text { OR }_{\text {adj }}\end{array}$ & $\begin{array}{l}\text { At least one } \\
\text { symptom last } \\
12 \text { months } \\
\text { OR }_{\text {adj }}\end{array}$ & $\begin{array}{l}\text { Physician- } \\
\text { diagnosed } \\
\text { asthma } \\
\text { OR }_{\text {adj }} \\
\end{array}$ \\
\hline \multicolumn{8}{|l|}{ Main categories } \\
\hline HMW agents & 1022 & 1.1 (0.93 to 1.3$)$ & $1.0(0.75$ to 1.4$)$ & $1.2(0.80$ to 1.7$)$ & $0.98(0.73$ to 1.3$)$ & 1.1 (0.91 to 1.3$)$ & $0.90(0.71$ to 1.1$)$ \\
\hline LMW agents & 584 & $1.2(0.97$ to 1.5$)$ & $1.2(0.86$ to 1.7$)$ & 1.1 (0.69 to 1.9$)$ & 0.94 (0.63 to 1.4$)$ & $1.2(0.94$ to 1.5$)$ & $0.99(0.73$ to 1.3$)$ \\
\hline Irritating agents & 2543 & 1.0 (0.91 to 1.2$)$ & $1.2(1.0$ to 1.5$)$ & $1.2(0.92$ to 1.6$)$ & $1.2(0.95$ to 1.5$)$ & $1.1(0.97$ to 1.3$)$ & $1.0(0.86$ to 1.2$)$ \\
\hline Peak exposure to irritants & 239 & 1.0 (0.70 to 1.5$)$ & $1.2(0.77$ to 2.0$)$ & $0.82(0.37$ to 1.8$)$ & $0.82(0.46$ to 1.5$)$ & 0.90 (0.64 to 1.3$)$ & $0.71(0.43$ to 1.2$)$ \\
\hline Uncertain or low exposure & 759 & 1.1 (0.85 to 1.3$)$ & 0.86 (0.59 to 1.2$)$ & $0.93(0.56$ to 1.6$)$ & 0.86 (0.59 to 1.3$)$ & $1.0(0.81$ to 1.2$)$ & $0.96(0.72$ to 1.3$)$ \\
\hline Reference group/unexposed $\ddagger$ & 5597 & 1 & 1 & 1 & 1 & 1 & 1 \\
\hline \multicolumn{8}{|l|}{ Detailed categories } \\
\hline Animal-derived agents & 165 & 0.97 (0.58 to 1.6$)$ & 0.94 (0.41 to 2.2$)$ & 1.1 (0.43 to 2.9$)$ & $0.61(0.21$ to 1.8$)$ & 0.91 (0.55 to 1.5$)$ & 1.1 (0.61 to 2.0$)$ \\
\hline Flour & 33 & $3.2(1.4$ to 7.3$)$ & 3.5 (1.3 to 9.5$)$ & $2.6(0.47$ to 15$)$ & $3.3(1.1$ to 10$)$ & $3.4(1.6$ to 7.6$)$ & $1.6(0.53$ to 4.7$)$ \\
\hline Mixed agricultural work (not animal) & 113 & 1.1 (0.68 to 1.8$)$ & $1.2(0.52$ to 2.7$)$ & $1.6(0.45$ to 5.4$)$ & 1.1 (0.45 to 2.6$)$ & $1.1(0.65$ to 1.7$)$ & $1.1(0.53$ to 2.1$)$ \\
\hline Moulds and other bioaerosols & 141 & $1.1(0.65$ to 2.0$)$ & $1.2(0.53$ to 2.8$)$ & $0.46(0.12$ to 1.8$)$ & $1.0(0.32$ to 3.3$)$ & $1.2(0.68$ to 2.0$)$ & $0.49(0.24$ to 1.0$)$ \\
\hline Latex proteins & 639 & $1.2(0.89$ to 1.7$)$ & $1.3(0.79$ to 2.1$)$ & $1.9(0.97$ to 3.6$)$ & $1.6(0.89$ to 2.7$)$ & $1.3(0.97$ to 1.8$)$ & $1.1(0.72$ to 1.7$)$ \\
\hline Pharmaceutical product agents & 474 & 0.87 (0.60 to 1.3$)$ & $0.60(0.33$ to 1.1$)$ & $0.54(0.25$ to 1.2$)$ & $0.44(0.22$ to 0.89$)$ & 0.74 (0.51 to 1.1$)$ & $0.83(0.50$ to 1.4$)$ \\
\hline Acrylates & 219 & $1.1(0.72$ to 1.7$)$ & $1.8(1.0$ to 3.4$)$ & $1.2(0.47$ to 3.1$)$ & $1.1(0.56$ to 2.2$)$ & $0.92(0.63$ to 1.4$)$ & $1.0(0.61$ to 1.8$)$ \\
\hline Epoxy chemicals & 187 & $0.63(0.31$ to 1.3$)$ & $0.11(0.034$ to 0.35$)$ & $0.15(0.024$ to 0.93$)$ & 0.55 (0.13 to 2.4$)$ & $0.54(0.27$ to 1.1$)$ & $0.89(0.30$ to 2.7$)$ \\
\hline Diisocyanates & 268 & $1.5(0.90$ to 2.6$)$ & 2.9 (1.5 to 5.7$)$ & $3.5(0.91$ to 13$)$ & $1.5(0.50$ to 4.5$)$ & $1.7(1.0$ to 2.9$)$ & $1.4(0.59$ to 3.4$)$ \\
\hline Other reactive agents & 195 & $1.2(0.83$ to 1.8$)$ & $0.93(0.48$ to 1.8$)$ & $1.2(0.57$ to 2.6$)$ & $0.73(0.36$ to 1.5$)$ & $1.1(0.77$ to 1.6$)$ & 0.69 (0.39 to 1.2$)$ \\
\hline Cleaning agents & 223 & $0.91(0.60$ to 1.4$)$ & $1.1(0.61$ to 2.0$)$ & $1.2(0.56$ to 2.6$)$ & $1.3(0.73$ to 2.3$)$ & $1.0(0.71$ to 1.5$)$ & $0.96(0.58$ to 1.6$)$ \\
\hline Wood and paper dust & 288 & $1.0(0.73$ to 1.5$)$ & 0.95 (0.56 to 1.6$)$ & $1.8(0.84$ to 4.0$)$ & $1.2(0.68$ to 2.3$)$ & $1.1(0.77$ to 1.5$)$ & $1.3(0.81$ to 2.0$)$ \\
\hline Inorganic dust and fumes & 789 & 1.0 (0.78 to 1.3$)$ & 1.3 (0.90 to 2.0$)$ & $1.0(0.54$ to 1.9$)$ & 0.84 (0.53 to 1.3$)$ & 1.0 (0.82 to 1.3$)$ & $0.77(0.54$ to 1.1$)$ \\
\hline $\begin{array}{l}\text { Welding and soldering fumes } \\
\text { and other metal dust }\end{array}$ & 134 & $1.6(0.88$ to 3.0$)$ & $3.2(1.6$ to 6.4$)$ & $0.90(0.24$ to 3.4$)$ & $1.2(0.51$ to 3.0$)$ & $1.8(1.0$ to 3.2$)$ & $1.6(0.73$ to 3.4$)$ \\
\hline Metal working fluids & 191 & 0.83 (0.52 to 1.3$)$ & $0.36(0.16$ to 0.84$)$ & 1.4 (0.56 to 3.4$)$ & 0.81 (0.38 to 1.7$)$ & $0.72(0.46$ to 1.1$)$ & $0.72(0.38$ to 1.4$)$ \\
\hline Vehicle/motor exhaust & 1124 & $1.1(0.95$ to 1.4$)$ & 1.4 (1.0 to 1.8$)$ & $1.3(0.88$ to 1.9$)$ & 1.4 (1.0 to 1.8$)$ & $1.2(1.0$ to 1.4$)$ & $1.2(0.93$ to 1.5$)$ \\
\hline Environmental tobacco smoke & 210 & $0.92(0.63$ to 1.4$)$ & 1.5 (0.92 to 2.6$)$ & $1.4(0.68$ to 2.8$)$ & $0.72(0.37$ to 1.4$)$ & $1.1(0.75$ to 1.5$)$ & 1.7 (1.1 to 2.6$)$ \\
\hline Peak exposure to irritants & 239 & $0.76(0.44$ to 1.3$)$ & $0.47(0.23$ to 0.95$)$ & $0.57(0.19$ to 1.7$)$ & $0.69(0.31$ to 1.5$)$ & $0.61(0.37$ to 1.0$)$ & $0.45(0.24$ to 0.84$)$ \\
\hline Uncertain or low exposure & 759 & $1.1(0.85$ to 1.3$)$ & 0.85 (0.59 to 1.2$)$ & $0.96(0.58$ to 1.6$)$ & 0.85 (0.58 to 1.2$)$ & 0.99 (0.81 to 1.2$)$ & $0.97(0.73$ to 1.3$)$ \\
\hline Reference group/unexposed $\dagger$ & 5597 & 1 & 1 & 1 & 1 & 1 & 1 \\
\hline
\end{tabular}

Results reaching significance, $p<0.05$, are marked in bold.

${ }^{*}$ Adjusted for age, gender, area of residence, smoking, passive smoking, housing conditions, damp and mould at home and nasal allergy.

tExposure was assessed by using N-JEM on the self-reported occupations categorised by the researchers using ISCO-88.

†The reference group are those with current occupations classified as unexposed only by N-JEM.

HMW, high molecular weight; ISCO-88, International Standard Classification of Occupations; LMW, low molecular weight; N-JEM, job-exposure matrix (JEM) developed for the northern European countries. 
Similar findings were seen in the ECRHS II cohort where elevated relative risks of asthma (RR 2.2, 95\% CI 1.0 to 4.5) were observed among nurses who reported using ammonia and/or bleach cleaning products more than once per week. ${ }^{24}$ In Norway, one might speculate that this group of healthcare workers including nursing assistants are more exposed to asthmagenic and/or irritating agents as they perform more activities related to cleaning and use of disinfectants compared with other healthcare workers, and also work more frequently in private homes where exposure to passive smoking may occur. Latex proteins were not identified as a risk factor by the use of N-JEM in our study. One reason may be that there has been considerable focus on the allergic properties of these proteins, leading to the use of alternatives.

Our findings also showed positive associations for respiratory symptoms and exposure to welding/soldering fumes, and for woken with dyspnoea and the occupational group welders. Welders are exposed to a variety of agents like LMW agents (metals), irritating gases/fumes and potentially high irritant peaks. These exposures have previously been associated with an increased risk of asthma. ${ }^{82728}$ A longitudinal study of Norwegian smelters also showed that low to moderate levels of dust exposure were associated with increased incidence of work-related asthma-like symptoms. ${ }^{29}$ However, as the CI for this finding was wide, this result must be interpreted with caution.

As shown in table 4, the study also identified negative associations between respiratory symptoms and exposures. For instance, a negative association was identified between physician-diagnosed asthma (OR 0.45 , CI 0.24 to 0.84 ) and woken with dyspnoea (OR 0.47 , CI 0.23 to $0.95)$ in regard to peak exposure to irritants. Some negative associations may be explained by residual confounding from socioeconomic status as it has been shown that airflow limitation may be related to education or income. ${ }^{30}$ Such effects must be considered when interpreting these results. Time-dependent analyses of the onset of symptoms and asthma in regard to occupational exposures will be considered in future data analyses.

The PAR for having at least one symptom during the past 12 months attributable to workplace factors was between $1 \%$ and $2 \%$, whereas the PAR for asthma attacks was $11 \%$ for the main occupational groups 2 and 4. A similar study from Sweden reported that proportion of asthma attributable to exposure groups varied from $3 \%$ to $14 \% .^{8}$ As that study assessed only new-onset asthma, the results are difficult to compare.

Occupational exposures were assessed by the use of a JEM. The occupational exposures associated with an increased risk of respiratory symptoms in the past 12 months were flour, diisocyanates, welding/soldering fumes and vehicle/motor exhaust. Among these exposures, flour exposure had the highest risk of respiratory symptoms. Flour is a well-known asthmagen. ${ }^{31}{ }^{32}$ Exposure to vehicle/motor exhaust was also associated with self-reported respiratory symptoms. Vehicle/motor exhaust is a complex mixture of different agent(s)/particles and therefore it is difficult to identify specific causal agents. Dumas et $a l^{27}$ showed that exposure to combustion particles/fumes was associated with physiciandiagnosed asthma with an OR of 2.04 (95\% CI 1.55 to 2.68). In addition, Henneberger $e t a l^{33}$ showed an association between severe exacerbation of asthma and exposure to combustion particles/fumes. Other studies have also shown associations between occupational exposures to diisocyanates and respiratory health outcomes that are consistent with our study findings. ${ }^{9}{ }^{34}$ The positive association between respiratory symptoms and exposure to welding/soldering fumes in the N-JEM supported the findings regarding this exposure from the ISCO- 88 data. The N-JEM findings confirm that certain occupational groups are still at high risk of being exposed to respiratory hazards in the workplace and that information regarding specific exposure is crucial to achieve targeted prevention of respiratory symptoms and diseases.

The low response rate of the Telemark study may be considered as an important limitation. To address nonparticipation, adjustments by inverse probability weighting were made to account for non-response bias. In a separate study in $2016,{ }^{19}$ we reported demographics characteristics, respiratory symptoms and use of asthma medication for the non-responders and identified possible selection bias. A total of 260 out of 700 randomly selected nonresponders $(37 \%)$ participated. No statistically significant differences were detected for asthma and several respiratory symptoms between those that responded to the Telemark study and those that did not. However, we adjusted the prevalence estimates for chronic cough and current use of asthma medication as these were overrepresented among the responders. Even though inverse probability of non-response weighting aims to adjust for non-response, results may still not be representative of the initial population. All the statistical analyses in this study were performed with and without weighted data sets to evaluate how adjusting for non-response affected the study results. We observed that the weights had little impact on the study outcomes. Regarding the external validity of the study, it may be argued that Telemark County includes an industrialised region (Grenland) and thus our results are not generalisable to the whole country. However, this would mainly affect the prevalences and to a lesser extent the associations between exposure and outcomes. Also, the similarity of some current findings to reports from other countries suggests our findings are relevant beyond Norway.

Another limitation may be that some of the occupational groups were small. In population-based studies, this will often be the case and implicates that effects have to be large to be detected. Thus, respiratory effects from some exposures and for some occupations may have been underestimated. On the other hand, the grouping of occupations by exposures may increase the study power to detect associations with respiratory outcomes. Further, JEM-derived data are considered to be 
less susceptible to recall bias leading to non-random misclassification of exposure than self-report because a JEM uses occupation and not exposures/measurements. We used an asthma-specific JEM that probably will identify well-known exposures associated with respiratory outcomes, but less likely to identify associations that are not well documented. Another limitation may be that the ISCO-88 classification is based on education and not on individual exposure information or measurements, which may lead to misclassification of exposure and underestimation of effects. Further studies should be performed to confirm these results including also exposure from previous jobs as our study addressed only current occupation.

Using a sample from the general population may reduce the probability of healthy worker effect. However, in cross-sectional analyses, selection out of the work force may occur. Negative associations between the occupational groups 4 and 5 (table 3) and physiciandiagnosed asthma may indicate this type of selection bias. However, our analyses of non-responders showed that their use of asthma medication was somewhat lower than among study participants, indicating that more severe asthmatics attended the study. The inclusion of subjects from the age of 16 may also to some extent have reduced the probability of selection bias in this cross-sectional analysis as some adolescents start their working life without further education or as apprentices. Apprentices may experience respiratory symptoms or develop occupational asthma leading to early selection out of certain jobs. Such effects may be difficult to capture in cross-sectional analyses which do not include this age group. However, the drawback is that many of these subjects do not have an occupational history resulting in a larger proportion of missing data.

Efforts were made to reduce the likelihood of selection, confounding and information bias as explained above. Also, the sample size was considered to ensure adequate statistical power for the reported associations. Thus, it can be argued that multiple testing procedures should not necessarily be used. ${ }^{35}$ Nevertheless, further studies should be performed to confirm our results regarding the impact of occupational exposure for specific jobs and exposures. As in most cross-sectional studies based on questionnaire data, we cannot exclude the presence of common method bias, but using current occupation instead of self-reported exposure may have reduced the possibility.

In conclusion, the prevalence of physician-diagnosed asthma was $11.5 \%$ in this sample from the general population. Analysis of risk factors contribute to the evidence that occupational exposure to flour, diisocyanates, welding/soldering fumes and vehicle/motor exhaust is associated with respiratory symptoms in the past 12 months and use of asthma medication. Selection bias may have been present although inverse probability of non-participation weighting was performed to counter this bias. Until prospective data are available, we recommend reduction of occupational exposures and early identification of workers with respiratory symptoms should remain an important priority.

\section{Author affiliations}

${ }^{1}$ Department of Occupational and Environmental Medicine, Telemark Hospital, Skien, Norway

${ }^{2}$ Institute of Clinical Medicine, Faculty of Medicine, University of Oslo, Oslo, Norway

${ }^{3}$ Department of Occupational and Environmental Medicine, Institute of Medicine, The Sahlgrenska Academy, University of Gothenburg, Gothenburg, Sweden

${ }^{4}$ Respiratory Health Division, National Institute for Occupational Safety and Health (NIOSH), Morgantown, West Virginia, USA

${ }^{5}$ Department of Respiratory Medicine, Oslo University Hospital, Oslo, Norway

Contributors RA, MVS, PKH, KT, JK and AKMF were involved in the design of the study. RA was involved in the data collection, data analyses, data management, data interpretation and primary manuscript preparation. AKMF was involved in the data collection, data management, data interpretation and critical revision of the manuscript. MVS was involved in the data collection, data analyses, data management, data interpretation and critical revision of the manuscript. EA contributed to the data interpretation and critical revision of the manuscript. KT was involved in data interpretation and critical revision of the manuscript. PKH was involved in data interpretation and critical revision of the manuscript. JK was involved in the data interpretation and critical revision of the manuscript. All authors provided input on the manuscript, and all authors read and approved the final manuscript.

Funding This work was supported by funding from Telemark Hospital, Norway.

Disclaimer The findings and conclusions in this report are those of the authors and do not necessarily represent the views of the National Institute for Occupational Safety and Health.

\section{Competing interests None declared}

Ethics approval This study was conducted with the approval of The Regional Committee for Medical and Health Research Ethics in Norway (REC 2012/ 1665).

Provenance and peer review Not commissioned; externally peer reviewed.

Data sharing statement No additional data are available.

Open Access This is an Open Access article distributed in accordance with the Creative Commons Attribution Non Commercial (CC BY-NC 4.0) license, which permits others to distribute, remix, adapt, build upon this work noncommercially, and license their derivative works on different terms, provided the original work is properly cited and the use is non-commercial. See: http:// creativecommons.org/licenses/by-nc/4.0/

\section{REFERENCES}

1. Frostad A, Søyseth V, Haldorsen $T$, et al. Respiratory symptoms and long-term cardiovascular mortality. Respir Med 2007;101:2289-96.

2. Voll-Aanerud M, Eagan TM, Wentzel-Larsen T, et al. Respiratory symptoms, COPD severity, and health related quality of life in a general population sample. Respir Med 2008;102:399-406.

3. Kogevinas M, Zock JP, Jarvis D, et al. Exposure to substances in the workplace and new-onset asthma; an international prospective population-based study (ECRHS-II). Lancet 2007;370:336-41.

4. Torén K, Blanc PD. Asthma caused by occupational exposures is common-a systematic analysis of estimates of the population-attributable fraction. BMC Pulm Med 2009;9:7.

5. Jakkola MS, Jakkola JJ. Assessment of public health impact of work-related asthma. BMC Med Res Methodol 2012;5:12-22.

6. Skorge TD, Eagan TM, Eide GE, et al. Occupational exposure and incidence of respiratory disorders in a general population. Scand $J$ Work Environ Health 2009;35:454-61.

7. Gundersen H, Magerøy N, Moen BE, et al. Low traffic and respiratory symptoms among smoking females: the Hordaland Health Study. Arch Environ Occup Health 2012;67:189-98. 
8. Lillienberg L, Andersson E, Janson C, et al. Occupational exposure and new-onset asthma in a population-based study in Northern Europe (RHINE). Ann Occup Hyg 2013;57:482-92.

9. Lillienberg L, Dahlman-Höglund A, Schöler L, et al. Exposures and asthma outcomes using two different job exposure matrices in a general population study in northern Europe. Ann Occup Hyg 2014:58:469-81.

10. Torén K, Ekerljung L, Kim JL, et al. Adult-onset asthma in west Sweden-Incidence, sex differences and impact of occupational exposures. Respir Med 2011;105:1622-8.

11. The National Institute of Occupational Health (STAMI). http://noa. stami.no/arbeidsmiljoindikatorer/helseutfallarbeidsskader/ helseplager/luftveisplager/ (accessed 8 Dec 2016).

12. The Norwegian Institute of Public Health. http://www.reseptregisteret no/Prevalens.aspx (accessed 11 Mar 2016).

13. European Community Respiratory Health Survey II Steering Committee. The European community respiratory health survey II. Eur Respir J 2002;20:1071-9.

14. Burney PG, Laitinen LA, Perdrizet $S$, et al. Validity and repeatability of the IUATLD (1984) Bronchial Symptoms Questionnaire: an international comparison. Eur Respir J 1989;2:940-5.

15. Kongerud J, Vale JR, Aalen OO. Questionnaire reliability and validity for aluminum potroom workers. Scand J Work Environ Health 1989;15:364-70.

16. Torén K, Brisman J, Järvholm B. Asthma and asthma-like symptoms in adults assessed by questionnaires. A literature review. Chest 1993;104:600-8.

17. ILO. International Standard Classification of Occupations ISCO 88. Geneva, Switzerland: ILO, 1991. ISBN 92-2-106438-7.

18. Fell AKM, Abrahamsen R, Henneberger PK, et al. Breath-taking jobs: a case-control study of respiratory work disability by occupation. Occup Environ Med 2016;73:600-6.

19. Abrahamsen R, Svendsen MV, Henneberger PK, et al. Nonresponse in a cross-sectional study of respiratory health in Norway. BMJ Open 2016;6:e009912.

20. Lötvall J, Ekerljung L, Rönmark EP, et al. West Sweden Asthma Study: prevalence trends over the last 18 years argues no recent increase in asthma. Respir Res 2009;10:94.

21. To T, Stanojevic S, Moores G, et al. Global asthma prevalence in adults: findings from the cross-sectional world health survey. BMC Public Health 2012;12:204.
22. Montnémery $P$, Bengtsson $P$, Elliot $A$, et al. Prevalence of obstructive lung diseases and respiratory symptoms in relation to living environment and socio-economic group. Respir Med 2001;95:744-52.

23. Statistics Norway. https://www.ssb.no/statistikkbanken/selectout/print asp?Fileformatld=2\&Queryfile=20161216105842489815693Lonn AnsMedKjNar\&PLanguage $=1 \&$ MainTable $=$ LonnAnsMedKjNar \&potsize $=100$ (accessed 16 Dec 2016)

24. Mirabelli MC, Zock JP, Plana E, et al. Occupational risk factors for asthma among nurses and related healthcare professionals in an international study. Occup Environ Med 2007;64:474-9.

25. Arif AA, Delclos GL, Serra C. Occupational exposures and asthma among nursing professionals. Occup Environ Med 2009;66:274-8.

26. Dumas O, Varraso R, Zock JP, et al. Asthma history, job type and job changes among US nurses. Occup Environ Med 2015;72:482-8.

27. Dumas $\mathrm{O}$, Laurent $\mathrm{E}$, Bousquet $\mathrm{J}$, et al. Occupational irritants and asthma: an Estonian cross-sectional study of 34,000 adults. Eur Respir J 2014;44:647-56.

28. Hedmer M, Karlsson JE, Andersson U, et al. Exposure to respirable dust and manganese and prevalence of airways symptoms, among Swedish mild steel welders in the manufacturing industry. Int Arch Occup Environ Health 2014;87:623-34.

29. Søyseth V, Johnsen HL, Henneberger PK, et al. The incidence of work-related asthma-like symptoms and dust exposure in Norwegian smelters. Am J Respir Crit Care Med 2012;185:1280-5.

30. Smith M, Li L, Augustyn M, et al. Prevalence and correlates of airflow obstruction in $\sim 317,000$ never-smokers in China. Eur Respir J 2014;44:66-77

31. Baur X, Degens PO, Sander I. Baker's asthma: still among the most frequent occupational respiratory disorders. J Allergy Clin Immunol 1998;102(Pt 1):984-97.

32. Meijster T, Warren N, Heederik D, et al. What is the best strategy to reduce the burden of occupational asthma and allergy in bakers? Occup Environ Med 2011;68:176-82.

33. Henneberger PK, Liang X, Lillienberg $L$, et al. Occupational exposures associated with severe exacerbation of asthma. Int J Tuberc Lung Dis 2015;19:244-50.

34. Torén K, Järvholm B, Brisman J, et al. Adult-onset asthma and occupational exposures. Scand J Work Environ Health 1999;25:430-5

35. Goldman M, Silbergeld E. Assuring access to data for chemical evaluations. Environ Helath Perspect 2013;121:149-52. 